DOI: https://doi.org/10.15407/techned2019.05.017

\title{
UNIFORM OF PULSE BARRIER DISCHARGE IN THE AIR OF ATMOSPHERIC PRESSURE IN THE PRESENCE OF WATER IN A DROP-FILM CONDITION
}

$\quad$ Journal
Publisher
ISSN
Issue
Pages

\author{
Tekhnichna elektrodynamika \\ Institute of Electrodynamics National Academy of Science of Ukraine \\ 1607-7970 (print), 2218-1903 (online) \\ No 5, 2019 (September/Oktober) \\ $17-20$
}

\author{
Authors \\ I.V. Bozhko*, V.O. Bereka** \\ Institute of Electrodynamics National Academy of Sciences of Ukraine, \\ pr. Peremohy, 56, Kyiv, 03057, Ukraine, \\ e-mail:ws77@ukr.net \\ * ORCID ID : http://orcid.org/0000-0002-7955-246X \\ ** ORCID ID : http://orcid.org/0000-0003-0888-2864
}

\begin{abstract}
It was shown the possibility of creating in atmospheric air in a plane-parallel gap in the presence of water with a drop-film state of a uniform pulsed barrier discharge, which was initiated by unipolar voltage pulses of amplitudes up to $28 \mathrm{kV}$ and fronts $\square 40 \mathrm{~ns}$ and duration about 100ns. Studies were carried out at thicknesses: the dielectric barrier is $2 \mathrm{~mm}$ and the gas gap $3 \mathrm{~mm}$. The characteristic dimensions of tap water drops were $1 \mathrm{~mm}$ and its films on the walls of the gas gap $\sim 0.1 \mathrm{~mm}$. For these conditions, the following amplitude discharge parameters were achieved: the electric field strength in the gas gap was about $60 \mathrm{kV} / \mathrm{cm}$, the current density $-2.6 \mathrm{~A} / \mathrm{cm}^{2}$, the electron concentration $-8.5 \cdot 10^{11} \mathrm{~cm}^{-3}$ with their average energy $-3,7 \mathrm{eB}$. The discharge becomes non-uniform: zones with bright filamentary formations appear in the gas gap when increasing of the frequency of repetition of voltage pulses over $\square 300 \mathrm{~Hz}$.. The limiting frequency of the discharge transition into an inhomogeneous form becomes significantly higher (more than $500 \mathrm{~Hz}$ ) with transverse purging of the gas gap with air, the speed of which at the
\end{abstract}


entrance to the electrode system is $0.6 \mathrm{~m} / \mathrm{s}$.

References 12, figures 7.

Key words: uniform and non-uniform pulsed barrier discharge, air, atmospheric pressure, drops and a film of water.

Received: 26.03.2019

Accepted: 23.04.2019

Published: 01.08.2019

\section{References}

1. Ulrich Kogelschatz. Dielectric-barrier Discharges: Their History, Discharge Physics, and Industrial Applications. Plasma Chemistry and Plasma Processing. 2003. Vol. 23. Issue 1. Pp. $1-46$. .1023/A:1022470901385

DOI: https://doi.org/10

2. Samoilovich V.G., Gibalov V.I., Kozlov K.V. Physical chemistry of the barrier discharge. Moskva: Moskovskii Gosudarstvennyi Universitet, 1989. 175 p. (Rus)

3. Golubovskii Yu.B., Maiorov V.A., Behnke J.F., Tepper J., Lindmayer M. Study of the homogeneous glow-like discharge in nitrogen at atmospheric pressure. Journal of Physics D:

Applied Physics 2004.

Vol. 37. Pp. 1346-1356.

4. Walsh J.L., Konga M.G. 10 ns pulsed atmospheric air plasma for uniform treatment of polymeric surfaces. Applied Physics Letters. 2007. Vol. 91. Pp. 251504 (3 pp). DOI: https://doi. org/10.1063/1.2825576

5. Shao Tao, Long Kaihua, Zhang Cheng, Yan Ping, Zhang Shichang, Pan Ruzheng.

Experimental study on repetitive unipolar nanosecond-pulse dielectric barrier discharge in air at atmospheric pressure. Journal of Physics D: Applied Physics. 2008. Vol. 41. P. 215203 (8 pp).

DOI:

https://doi.org/10.1088/0022-3727/41/21/215203

6. Shuai Zhang, Li Jia, Wen-chun Wang, De-zheng Yang, Kai Tang, Zhi-jie Liu. The influencing factors of nanosecond pulse homogeneous dielectric barrier discharge in air. Spectrochimica Acta. Part A: Molecular and Biomolecular Spectroscopy

. 2014. Vol. 117. Pp. 535-540.

DOI:

https://doi.org/10.1016/j.saa.2013.08.051

7. Bozhko I.V., Karlov A.N., Kondratenko I.P., Charnyj D.V. Development of complex for water 
treatment with pulse barrier discharge. Tekhnichna Elektrodynamika. 2017. No 6. Pp. 80-86. (Ukr). DOI:

10.15407/techned2017.06.080

https://doi.org/

8. Bo Jiang, Jingtang Zheng, Shi Qiu, Qinhui Zhang, Zifeng Yan, Qingzhong Xue. Review on electrical discharge plasma technology for wastewater. Chemical Engineering Journal. 2014. No 236. Pp. 348-363.

DOI:

https://doi.org/10.1016/j.cej.2013.09.090

9. Shen Zhao, Chunjing Hao, Di Xu, Yiyong Wen, Jian Qiu, Kefu Liu. Effect of Electrical Parameters on Energy Yield of Organic Pollutant Degradation in a Dielectric Barrier Discharge Reactor. IEEE Transactions on Plasma Science. 2017. Vol. 45. Issue 6. Pp. 1043 - 1050. DOI: https://doi.org/10.1109/TPS.2017.2691726

10. Gnapowski E., Gnapowski S., Pytka Ja. Effect of Mesh Geometry on Power, Efficiency, and Homogeneity of Barrier Discharges in the Presence of Glass Dielectric. IEEE Transactions on Plasma Science 2018.

Vol. 46. Issue 10. Pp. 3493 - 3498.

DOI:

https://doi.org/10.1109/TPS.2018.2816065

11. Bozhko I.V., Serdyuk Y.V. Determination of Energy of a Pulsed Dielectric Barrier Discharge and Method for Increasing Its Efficiency. IEEE Transactions on Plasma Science. 2017. Vol. 45. Issue 12. Pp. 3064 - 3069.

DOI:

https://doi.org/10.1109/TPS.2017.2760888

12. Yukinori Sakiyama, David B. Graves, Hung-Wen Chang, Tetsuji Shimizu, Gregor E., Morfill J. Plasma chemistry model of surface microdischarge in humid air and dynamics of reactive neutral species. Journal of Physics D: Applied Physics. 2012. Vol. 45. P. 425201 (19 pp). DOI: https://doi.org/10.1088/0022-3727/45/42/425201

PDF 